\title{
PENGARUH PENGGUNAAN TEPUNG RUMPUT LAUT (Gracilaria verrucosa) FERMENTASI DALAM RAMSUM AYAM BROILER TERHADAP BERAT DAN UKURAN TULANG FEMUR, TIBIA DAN TARSOMETATARSUS
}

\author{
Ardhianto R. ${ }^{1}$, L.D. Mahfudz ${ }^{2}$ dan E. Suprijatna ${ }^{2}$ \\ 1) Mahasiswa Fakultas Peternakan Dan Pertanian Universitas Diponegoro \\ Kampus drh. Soejono Koesoemowardojo Tembalang Semarang 50275 \\ E-mail: re.ardhianto@gmail.com \\ ${ }^{2)}$ Fakultas Peternakan dan Pertanian, Universitas Diponegoro \\ Kampus drh. R. Soejono Kusumowardojo Tembalang, Semarang 50275
}

Diterima: 16 Agustus 2016

Disetujui: 08 November 2016

\begin{abstract}
ABSTRAK
Penelitian ini bertujuan untuk mengetahui pengaruh penggunaan tepung rumput laut (Gracilaria verrucosa) terfermentasi sebagai bahan penyusun ransum ayam broiler terhadap berat, panjang dan lebar tulang femur, tibia dan tarsometatarsus. Materi yang digunakan adalah ayam broiler jantan dan betina sebanyak 150 ekor umur 7 hari dengan bobot 163,38 $\pm 24,67 \mathrm{~g}(\mathrm{CV} 3,04)$. Bahan pakan yang digunakan dalam penelitian ini adalah tepung Gracilaria verrucosa terfermentasi, bekatul, jagung kuning giling, tepung ikan, bungkil kedelai, PMM, minyak nabati, $\mathrm{CaCO}$, topmiks. Ransum disusun dengan kandungan protein $21 \%$, EM $3000 \mathrm{kal} / \mathrm{g}$. Rancangan percobaan yang digunakan adalah rancangan acak lengkap (RAL) yang terdiri dari 5 perlakuan, setiap perlakuan diulangi sebanyak 6 kali, setiap unit percobaan terdiri dari 5 ekor ayam broiler. Ransum perlakuan yaitu sebagai berikut : $\mathrm{T} 0=$ ransum tanpa tepung rumput laut; $\mathrm{T} 1=$ ransum menggunakan tepung rumput laut 5\%; T2=ransum menggunakan tepung rumput laut fermentasi 5\%; dan $\mathrm{T} 3=7,5 \%$; sisa $\mathrm{T} 4=10 \%$. Hasil penelitian menunjukan bahwa berat, panjang dan lebar tulang femur, tibia dan tarsometatarsus serta berat hidup ayam broiler tidak mengalami perubahan yang signifikan $(\mathrm{P}>0,05)$ dalam penggunaan tepung rumput laut terfermentasi dalam ransum hingga level $10 \%$. Kesimpulan yang diperoleh yaitu penggunaan tepung rumput laut (Gracilaria verrucosa) fermentasi dalam ransum tidak memberikan pengaruh yang nyata terhadap berat, panjang dan lebar tulang femur, tibia dan tarsometatarsus serta berat hidup ayam broiler.
\end{abstract}

Kata kunci : ayam broiler, tepung rumput laut terfermentasi, pertulangan, berat hidup.
THE UTILIZATION OF FERMENTED SEAWEED (Gracilaria Verrucosa) MEAL IN BROILER RATION ON THE WEIGHTS AND SIZE OF FEMUR, TIBIA AND TARSOMETATARSUS BONE

\begin{abstract}
This study was aimed to determine the use of fermented seaweed (Gracilaria verrucosa) meal as feed stuff in the ration on the weight and size the femur, tibia and tarsometatarsus of Broiler. The materials used ware of male and female broiler as much as


150 birds 7 at days old with average body weights 163,38 $\pm 24,67 \mathrm{~g}$ (CV 3, 04). Feed ingredients was used in this study are Gracilaria verrucosa fermented meal, rice brand, yellow corn meal, fish meal, soybean meal, PMM, vegetable oil, CaCO3 and topmiks. The experimental design used was RAL consisting of 5 treatments, each treatment was performed 6 times replications, each experimental unit consisted of 5 chickens with the following treatments : T0=ration with out the use of seaweed meal; T1=ration the use of seaweed meal 5\%; T2=5\%; T3=7.5\%; T4=10\%. The results showed that the weight and size of femur, tibia and tarsometatarsus and severe living broiler chicken not experienced significant different $(P>0.05)$ in the use of fermented seaweed in rations to a level of $10 \%$. The conclusion by the use of fermented seaweed meal (Gracilaria verrucosa) in rations are not affected to the body weight and size of femur, tibia and tarsometatarsus and severe living broiler.

Keywords : broiler, fermented seaweed meal, bone.

\section{PENDAHULUAN}

Ayam broiler merupakan ternak yang sangat cepat pertumbuhannya, namun pertumbuhan tulang tidak secepat dengan pertumbuhan dagingnya sehingga sering terjadi abnormalitas pada tulang, khususnya tulang femur, tibia dan tarsometatarsus. Pertumbuhan ayam broiler yang cepat dan besar haruslah didukung dengan tulang yang besar dan kuat, khususnya tulang femur, tibia dan tarsometatarsus guna menopang tubuh ayam broiler tersebut.

Pakan berperan penting terhadap perkembangan sistem kerangka dan pertumbuhan tulang serta berkaitan erat dengan pertumbuhan bagian-bagian tubuh seperti otot, dan lemak (Card and Neshein, 1972). Sumber mineral terbaik adalah bahan pakan yang berasal dari laut misalnya tepung rumput laut dan tepung ikan (Horhoruw et al., 2009). Rumput laut jenis alga merah merupakan salah satu potensi sumber daya laut yang produksinya melimpah tetapi belum banyak dimanfaatkan di Indonesia. Rumput laut kaya akan karbohidrat, serat terlarut, vitamin serta mineral seperti kalsium yang dapat digunakan untuk membantu pertumbuhan dan perkembangan kerangka tubuh. Mineral dalam rumput laut memegang peranan penting dalam tubuh diantaranya sebagai komponen penyusun tulang dan proses metabolisme. Kalsium (Ca) merupakan mineral paling banyak yang terdapat dalam tubuh dan 99\% ditemukan di kerangka. Fungsi dari kalsium adalah untuk membentuk rangka yang kuat serta melindungi organ yang penting serta membantu pergerakan dan pertumbuhan (Tillman et al., 1991). Gracilaria verrucosa mengandung Serat Kasar (SK) yang tinggi oleh karena itu perlu di fermentasi terlebih dahulu untuk menurunkan kadar SK tersebut sebelum digunakan sebagai bahan pakan.

Penelitian ini bertujuan untuk mengetahui penggunaan tepung rumput laut (Gracilaria verrucosa) terfermentasi dalam ransum ayam broiler terhadap berat dan ukuran tulang femur, tibia, dan tarsometatarsus. Manfaat dari penelitian ini adalah mengetahui sejauh mana pengaruh penggunaan tepung rumput laut dalam ransum ayam broiler terhadap berat dan ukuran tulang femur, tibia, dan tarsometatarsus.

\section{MATERI DAN METODE}

Materi yang digunakan dalam penelitian ini adalah ayam broiler jantan dan betina sebanyak 150 ekor umur 7 hari dengan bobot 163,38 $\pm 24,67 \mathrm{~g}(\mathrm{CV} 3,04)$. 
Bahan pakan yang digunakan dalam penelitian ini adalah tepung Gracilaria verrucosa terfermentasi, ragi tape jerami (dengan kandungan Aspergillus niger, Rhizopus dan Acetobacter) bekatul, jagung kuning giling, tepung ikan, bungkil kedelai, Poultry Meat Meal (PMM), minyak nabati, $\mathrm{CaCO} 3$, topmiks. Unit kandang yang digunakan dalam penelitian berjumlah 30 unit yang setiap unit berisi 5 (lima) ekor ayam broiler. Ransum yang diberikan pada ayam pedaging (broiler) berumur $1-6$ hari adalah ransum komersial jenis BR-1. Komposisi dan kandungan nutrisi ransum penelitian dapat dilihat pada Tabel 1.

Tabel 1. Komposisi dan Kandungan Nutrisi Ransum Perlakuan

\begin{tabular}{|c|c|c|c|c|c|}
\hline \multirow{2}{*}{ Bahan Pakan } & \multicolumn{5}{|c|}{ Ransum } \\
\hline & T0 & T1 & $\mathrm{T} 2$ & T3 & T4 \\
\hline & \multicolumn{5}{|c|}{------------------------- (\%) ---------------------- } \\
\hline Jagung & 48,00 & 50,90 & 50,00 & 48,50 & 47,00 \\
\hline Bekatul & 13,00 & 7,70 & 8,50 & 9,20 & 9,20 \\
\hline Bkk & 28,80 & 28,00 & 28,00 & 27,00 & 26,00 \\
\hline Tepung ikan & 5,00 & 5,00 & 5,00 & 5,00 & 5,00 \\
\hline PMM & 2,00 & 2,00 & 2,00 & 2,00 & 2,00 \\
\hline Minyak Nabati & 1,50 & 1,00 & 1,00 & 0,30 & 0,30 \\
\hline $\mathrm{CaCO}_{3}$ & 1,20 & 0,20 & 0,30 & 0,20 & 0,20 \\
\hline Topmiks & 0,50 & 0,20 & 0,20 & 0,30 & 0,30 \\
\hline Rumput Laut & - & 5,00 & - & - & - \\
\hline RL Fermentasi & - & - & 5,00 & 7,50 & 10,00 \\
\hline Jumlah & 100,00 & 100,00 & 100,00 & 100,00 & 100,00 \\
\hline \multicolumn{6}{|l|}{ Kandungan Nutrient } \\
\hline Energi Metabolis $(\mathrm{Kkal} / \mathrm{kg}) * *$ & 3028,29 & 3004,06 & 3088,02 & 3062,10 & 3057,90 \\
\hline Protein $(\%)^{*}$ & 21,12 & 21,03 & 21,24 & 21,16 & 21,01 \\
\hline Lemak Kasar $(\%)^{*}$ & 7,26 & 6,85 & 6,78 & 5,96 & 5,81 \\
\hline Serat Kasar $(\%)^{*}$ & 4,68 & 4,37 & 4,18 & 4,30 & 4,32 \\
\hline Kalsium $(\%)^{*}$ & 1,07 & 2,31 & 2,09 & 2,67 & 3,29 \\
\hline Fosfor $(\%)^{*}$ & 0,59 & 1,47 & 1,33 & 1,70 & 2,02 \\
\hline \multicolumn{6}{|c|}{$\begin{array}{l}\text { * Hasil Analisis Proksimat di Laboratorium Ilmu Makanan Ternak, Fakultas Peternakan } \\
\text { dan Pertanian, Universitas Diponegoro (2013). }\end{array}$} \\
\hline \multicolumn{6}{|l|}{ ** Hasil Perhitungan berd } \\
\hline
\end{tabular}

Rancangan percobaan menggunakan Rancangan Acak Lengkap (RAL) yang terdiri dari 5 perlakuan, setiap perlakuan diulangi sebanyak 6 kali, setiap unit percobaan terdiri dari 5 ekor ayam broiler. Ransum perlakuan yaitu sebagai berikut: T0 (Ransum tanpa tepung rumput laut); T1

(Ransum menggunakan tepung rumput laut 5\%); T2 (Ransum menggunakan tepung rumput laut fermentasi 5\%); T3 (Ransum menggunakan tepung rumput laut fermentasi 7,5\%); T4
(Ransum menggunakan tepung rumput laut fermentasi 10\%).

Data yang diperoleh dianalisis menggunakan prosedur analisis ragam dengan uji $\mathrm{F}$ pada taraf $5 \%$ dan apabila hasil analisis menunjukkan pengaruh perlakuan yang nyata dilanjutkan dengan uji wilayah ganda Duncan untuk mengetahui perbedaan antar perlakuan (Stell and Torrie, 1993). 
HASIL DAN PEMBAHASAN

Data hasil penelitian pengaruh perlakuan terhadap berat, panjang dan lebar tulang femur, tibia dan tarsometatarsus ayam broiler pada perlakuan T0, T1, T2, T3 dan T4 dapat dilihat pada Tabel 2.

Tabel 2. Rataan Berat, Panjang dan Lebar Tulang Femur, Tibia dan Tarsometatarsus serta Berat Hidup Ayam Broiler

\begin{tabular}{clccccc}
\hline \multirow{2}{*}{ Variabel } & \multirow{2}{*}{ Parameter } & \multicolumn{5}{c}{ Perlakuan } \\
\cline { 3 - 7 } & & T0 & T1 & T2 & T3 & T4 \\
\hline \multirow{2}{*}{ Femur } & Berat $(\mathrm{g})$ & 7,70 & 7,70 & 8,32 & 7,73 & 7,00 \\
& Panjang $(\mathrm{cm})$ & 6,38 & 6,03 & 6,26 & 6,33 & 6,16 \\
& Lebar $(\mathrm{cm})$ & 0,76 & 0,86 & 0,83 & 0,85 & 0,76 \\
\hline \multirow{2}{*}{ Tibia } & Berat $(\mathrm{g})$ & 10,34 & 9,91 & 10,41 & 10,15 & 9,24 \\
& Panjang $(\mathrm{cm})$ & 8,53 & 8,35 & 8,38 & 8,43 & 8,18 \\
& Lebar $(\mathrm{cm})$ & 0,70 & 0,70 & 0,66 & 0,71 & 0,66 \\
\hline \multirow{2}{*}{ Tarso } & Berat $(\mathrm{g})$ & 7,25 & 6,61 & 7,03 & 7,70 & 6,74 \\
metatarsus & Panjang $(\mathrm{cm})$ & 6,13 & 6,13 & 6,21 & 6,28 & 6,11 \\
& Lebar $(\mathrm{cm})$ & 0,86 & 0,88 & 0,88 & 0,88 & 0,76 \\
\hline \multirow{2}{*}{ merata } & $1193,22^{\text {ns }}$ & $1203,31^{\text {ns }}$ & $1252,72^{\text {ns }}$ & $1204,88^{\text {ns }}$ & $1090,72^{\text {ns }}$ \\
\hline
\end{tabular}

${ }^{\mathrm{ns}}$ Non signifikan $(\mathrm{P}>0,05)$

\section{Tulang Femur}

Pengaruh penggunaan tepung rumput laut fermentasi hingga level $10 \%$ memberikan perbedaan yang tidak nyata $(\mathrm{P}>0,05)$ terhadap berat, panjang dan lebar tulang femur pada perlakuan T0, T1, T2, T3 maupun T4. Menurut Sullivan (1994) di sitasi oleh Enny (2002), kecepatan mineralisasi tulang femur terjadi lebih lambat dibandingkan tulang tibia dan hal ini diduga bahwa tulang femur merupakan rangkaian penyebab abnormalitas perkembangan tulang panjang. Demikian juga menurut pendapat Forest et al., (1975), bahwa pertumbuhan yang paling cepat adalah tulang dan setelah tercapai ukuran maksimal pertumbuhan tulang akan terhenti, tulang lebih dulu tumbuh karena merupakan rangka yang menentukan konformasi otot.

Pertumbuhan tulang yang sebenarnya dapat terjadi melalui dua proses yaitu endochondral dan intramembranous ossification, kemudian diikuti dengan perubahan struktur tulang dan perkembangan kerangka (Lawrence and
Fowler, 2002). Tidak adanya pengaruh penggunaan rumput laut fermentasi terhadap berat dan ukuran tulang femur dikarenakan berat hidup dan konsumsi ransum yang rendah, serta kandungan nutrien dalam ransum hampir sama untuk setiap perlakuannya. Amrullah (2004) menyatakan bahwa ayam broiler mampu mengubah ransum menjadi daging secara efisien dalam waktu 5-6 minggu. Bobot badan yang dihasilkan berkisar dalam penelitian antara 1460-1915 g/ekor. Rendahnya bobot badan ini disebabkan oleh konsumsi ransum yang rendah/sedikit sehingga kebutuhan nutrisi bagi tubuh ayam belum terpenuhi dan pertumbuhan tulang dan daging kurang maksimal. Wahju (2004) menyatakan bahwa faktor yang mempengaruhi pertumbuhan ayam broiler antara lain faktor nutriononal yang meliputi protein, vitamin dan mineral (kalsium, fosfor, natrium, kalium) serta faktor material meliputi genetik, jenis kelamin, umur, penyakit dan manajemen pemeliharaan. 


\section{Tulang Tibia}

Hasil analisis sidik ragam menunjukkan bahwa perlakuan ransum yang mengandung tepung rumput laut fermentasi berbeda tidak nyata $(\mathrm{P}>0,05)$ terhadap berat dan ukuran tulang tibia, yang artinya penggunaan tepung rumput laut fermentasi hingga $10 \%$ dalam ransum, tidak berpengaruh terhadap berat dan ukuran tulang tibia dan merespon sama terhadap semua ransum perlakuan, sehingga tidak mempengaruhi berat dan ukuran tulang tibia.

Protein sangat berperan dalam proses pertumbuhan tulang tibia. Demineralisasi tulang tibia merupakan faktor penting untuk mengetahui kemampunan tulang tibia dalam menopang berat badannya sehingga dapat terhindar dari terjadinya dyschondroplasia yang banyak terdapat pada ayam broiler baik jantan maupun betina (Lilburn, 1993). Menurut Pudyani (2005), kekurangan protein menyebabkan hambatan kalsifikasi tulang sehingga pembentukan matriks organik akan terhambat. Ini akan menyebabkan berkurangnya deposisi mineral terutama kalsium dan fosfor dalam matriks tulang. Tidak adanya pengaruh penggunaan rumput laut fermentasi terhadap berat dan ukuran tulang tibia dikarenakan konsumsi ransum yang dihasilkan dalam penelitian tergolong rendah, yaitu dengan rata-rata 3408,91 gram. Hasil ini lebih rendah dibandingkan dengan standar Japfa (2012) yang menunjukkan konsumsi ransum ayam broiler pada umur 5 minggu sebesar 3.670 gram. Card dan Neshein (1972) menyatakan bahwa konsumsi ransum dengan jumlah yang tinggi dapat meningkatkan pertumbuhan berat badan. Bobot badan yang tinggi menunjukkan pertumbuhan daging yang baik serta semakin besar konformasi tulang yang dibentuk sebagai tempat melekatnya daging dan menopang tubuh. Bobot badan berkorelasi positif dengan ukuran dan berat tulang tibia (Sartika, 2000).

\section{Tulang Tarsometatarsus}

Pertambahan berat, panjang dan lebar tulang akan berjalan beriringan. Pada saat ini pertumbuhan tulang tarsometatarsus masih dalam proses penyempurnaan karena tulang tarsometatarsus memiliki pertumbuhan yang lebih lambat dibandingkan dengan pertumbuhan tulang lainnya (Cendrawati, 2007). Berat, panjang dan lebar tulang tarsometatarsus tidak berpengaruh nyata pada pemberian tepung rumput laut fermentasi hingga level 10\%, disebabkan oleh pertumbuhan berat, panjang dan lebar tulang tarsometatarsus sudah mencapai formasi akhir. Menurut Anggorodi (1995), kandungan energi ransum dan konsumsi ransum mempunyai korelasi negatif, semakin tinggi kandungan energi ransum maka konsumsi ransum semakin rendah dan sebaliknya. Tillman et al., (1998) menyatakan bahwa ayam mengkonsumsi ransum untuk mencukupi kebutuhan energi dan setelah terpenuhi kebutuhan energinya ayam akan berhenti mengkonsumsi ransum. Menurut pendapat Murtidjo (1997), tinggi rendahnya ransum pada unggas dipengaruhi oleh kandungan energi metabolis di dalam ransum, konsumsi ransum akan rendah apabila kandungan energi metabolisnya tinggi, konsumsi ransum akan lebih tinggi pada ransum dengan kandungan energi metabolis rendah.

\section{SIMPULAN DAN SARAN Simpulan}

Berdasarkan hasil penelitian dan pembahasan dapat disimpulkan bahwa penggunaan tepung rumput laut (Gracilaria 
verrucosa) terfermentasi dalam ransum tidak memberikan pengaruh yang nyata terhadap berat dan ukuran tulang femur, tibia dan tarsometatarsus. Rumput laut terfermentasi dapat digunakan dalam ransum ayam broiler sampai dengan $10 \%$.

\section{Saran}

Untuk penelitian selanjutnya perlu diperhitungkan pemberian tepung rumput laut (Gracilaria verrucosa) fermentasi dalam bentuk pakan crumble atau pellet agar lebih efisien.

\section{DAFTAR PUSTAKA}

Amrullah, I. K. 2004. Nutrisi Ayam. Lembaga Satu Gunung Budi. Bogor.

Anggorodi, R. 1994. Ilmu Makanan Ternak Umum. Penerbit PT. Gramedia, Jakarta.

Applegate, T. J dan Lilburn, M. S. 2002. Growth of the Femur and Tibia of a Commercial Broiler Line. Poultry Sci. 81:1289-1294.

Card, L, E. and M. C. Nesheim. 1972. Poultry Production. $11^{\text {th }}$ Ed. Lea and Febiger, Philadelphia, California.

Cendrawati, V. Y. 2007. Studi Ukuran dan Bentuk Tubuh Ayam Kampung, Ayam Sentul dan Ayam Wareng Tangerang. Skripsi. Fakultas Peternakan Institut Pertanian Bogor, Bogor.

Charoen Pokphand Indonesia. 2006 Manual

Broiler Manajemen CP 707.

Charoen Pokphand Indonesia, Jakarta.

Enny, Y. W., Yuniwarti dan T. R. Saraswati.2002. Aktifitas Klasifikasi Tulang Tibia Broiler
Jantan dan Betina Setelah Pemberian 1,25Dihidroxycholecalciferol.Laporan Penelitian. Universitas Diponegoro, Semarang.

Forest, J.C., E.D. Aberle, H.B. Hendrick, M.M. Judge and R.A. Markel. 1975. Principie Of Meat Science. W.H. Freeman and Co, San Fransisco.

Horhoruw, W. M., Wihandoyo, dan Tri Y. 2009. Pengaruh pemanfaatan rumput laut Gracilaria edulis dalam pakan terhadap kinerja ayam. Buletin Peternakan Vol. 33(1).

Japfa Comfeed Indonesia. 2012. Performa Broiler MB 202. PT. JCI, Jakarta.

Lawrence, T. L. J And V. R. Fowler. 2002. Growth of Farm Animal. Cab. International, New York.

Murtidjo, B. A. 1997. Mengelola Ayam Buras. Kanisius, Yogyakarta.

Nurdjana, M. L. 2005. Iklim Usaha yang Kondusif Bagi Pengembangan Akuakultur di Indonesia. Makalah Konferensi Nasional Akuakultur di Indonesia. Makassar. 23-25 November 2005. 15pp.

Pudyani, P. S. 2005. Reversibilitas kalsifikasi tulang akibat kekurangan protein pre dan post natal. Maj. Ked. Gizi. 38 (3):115-119.

Sartika, T. 2000. Studi Keragaman Fenotipik dan Genetik Ayam Kampung (Gallus gallus domesticus) pada Populasi Dasar Seleksi. Program Pascasarjana. Institut Pertanian Bogor, Bogor. (Tesis Magister Ilmu Ternak).

Stell, R. G. D. dan J. H. Torrie. 1993. Prinsip dan Prosedur Statistika: 
Suatu Pendekatan Biometrik.

Penerbit Gramedia Pustaka Utama,

Jakarta. Terjemahan B. Sumantri.

Tillman, A., D. Hartadi, H. S.

Reksohadiprodjo, $\mathrm{S}$.

Prawirokusumo dan S.

Lebdosoekojo. 1998. Ilmu Makanan

Ternak Dasar. Gajah Mada

University Press, Yogyakarta.

Wahju, J. 2004. Ilmu Nutrisi Unggas.

Cetakan ke 5. Gajah Mada

University, Yogyakarta. 